\title{
Karyomorphological studies of Aponogeton appendiculatus Bruggen and Aponogeton crispus Thunb.
}

\author{
S.P. Gaikwad ${ }^{1}$, S.R. Yadav $^{2}$, R.D. Gore ${ }^{1 *}$ and K.U. Garad ${ }^{1}$ \\ ${ }^{1}$ Life Science Research Laboratory, Walchand College of Arts and Science, Solapur- 413006 (MS), India. \\ ${ }^{2}$ Department of Botany, Shivaji University, Kolhapur- 416004 (MS), India.
}

Revised: 10 October 2013; Accepted: 28 November 2013

\begin{abstract}
The study focused on the correct taxonomic identification and the determination of somatic chromosome numbers of Aponogeton appendiculatus Bruggen and Aponogeton crispus Thunb. A somatic chromosome number of $2 \mathrm{n}=30$ and $2 \mathrm{n}=32$ was observed in A. appendiculatus and A. crispus, respectively. The chromosomes of both species were short with median to submedian primary constriction. The karyotypes were reasonably symmetrical, indicating the primitiveness of the family in general.
\end{abstract}

Keywords: Aponogeton appendiculatus, Aponogeton crispus, India, karyomorphology.

\section{INTRODUCTION}

The monogeneric family Aponogetonaceae is represented by about 45 species of Aponogeton L. f., mainly distributed in the tropics and subtropics of the Old World (Bruggen, 1985). In India, the genus is represented by 7 species (Bruggen, 1985; Raghavan, 1996; Yadav \& Gaikwad, 2003) of which $A$. appendiculatus Bruggen, A. bruggenii Yadav \& Govekar and A. satarensis Raghavan et al. are narrow, endemic and critically endangered (Ahmedullah \& Nayar, 1986; Nayar, 1996; Raghavan, 1996; Mishra \& Singh, 2001; Yadav \& Gaikwad, 2003) and are included in the Indian Red Data Book (Nayar \& Sastry, 1987, 1988). The remaining Indian species, namely $A$. crispus Thunb., A. natans (L.) Engler Krause and A. undulatus Roxburgh are widely distributed almost throughout India, however, A. lakhonensis Camus, is known from the eastern part of the country i.e. Assam, Meghalaya and Nagaland (Raghavan, 1996; Yadav \& Gaikwad, 2003).

The cytological studies of some species of Aponogeton have been carried out by several workers viz.
Harada, 1956; Sharma \& Chatterjee, 1967; Misra, 1972; Raven, 1975; Davidse, 1981; Ghosh \& Bhattacharya, 1980; Arends, 1985; Yadav et al., 1989; Yadav, 1995a, b; Gaikwad et al., 1998. However, the knowledge on the cytology of the family is far from satisfactory. Arends (1985) stated that in Indian literature, somatic chromosome reports for A. crispus, A. natans and A. undulatus are often problematic due to taxonomic misidentification. Hence, the present investigation was focused on the correct taxonomic identification and the determination of somatic chromosome numbers with karyomorphology studies of Aponogeton appendiculatus and Aponogeton crispus.

A. appendiculatus is endemic to the coastal region of the Kerala and Tamil Nadu States of India. It grows in brackish water streams of $1-1.5 \mathrm{~m}$ depth in the vicinity of the sea. It can be distinguished from other Indian Aponogeton species by its brackish water habitat, submerged leaves and seeds with 4-6 linear tortuous appendages. A. crispus is widely distributed in India and is recorded from several states such as Andhra Pradesh, Karnataka, Kerala, Maharashtra, Tamil Nadu and West Bengal. It is also found in Sri Lanka. The plant grows in permanent fresh water lakes, ponds and pools and have both floating and submerged leaves. It produces both smooth as well as echinate follicles.

\section{METHODS AND MATERIALS}

Tubers of Aponogeton appendiculatus were collected from North Paravoor on the way to Alwaya in the Trichur District of the Kerala State in the vicinity of 
the sea, and that of Aponogeton crispus from near Banglore in the Karnataka State. The tubers were transplanted in plastic tubs and cement tanks in the Botanical Garden.

For karyotypic studies, healthy root tips were used after pretreatment with p-dichlorobenzene for $3-4 \mathrm{~h}$ at $12{ }^{\circ} \mathrm{C}( \pm 1)$. The slides were prepared by the usual smear technique suggested by Burrell (1939). Propionic orcein $(2 \%)$ was used as the stain. The measurement of chromosomes was made from photos of 20 different somatic plates. Chromosome classification was done following the nomenclature of chromosomes proposed by Levan et al. (1964). The total form percentage (TF \%) was calculated by using the formulae given by Huziwara (1962). The symmetry index (SI) was calculated by using the formulae given by Pritchard (1967).
All photomicrographs were taken from temporary preparations using MEAK's system of Janaval Carl Zeiss microscope.

\section{RESULTS}

\section{Aponogeton appendiculatus H. Bruggen. Blumea 16: 265, f. 5.1968.}

A somatic chromosome number of $2 n=30$ was observed in the species (Figure 1a) and in general, the chromosomes were short $(1.91-4.53 \mu \mathrm{m})$. The chromosome length ranged between $1.91-4.53 \mu \mathrm{m}$ with a mean length of $2.96 \mu \mathrm{m}$ and an absolute length of $44.46 \mu \mathrm{m}$ (Table 2). TF \% was $37.11 \mu \mathrm{m}$ and the symmetrical index was 59.01. The idiogram of the species is represented in Figure 2.

Table 1: Somatic chromosome number reported for Indian Aponogeton species

\begin{tabular}{clcl}
\hline $\begin{array}{c}\text { Serial } \\
\text { no. }\end{array}$ & Name of the species & $\begin{array}{c}\text { Chromosome } \\
\text { number }(2 \mathrm{n})\end{array}$ & Author and year of publication \\
\hline 1 & A. appendiculatus & 30 & Gaikwad et al., 1998 \\
2 & A. bruggenii & 56 & Yadav, 1995a \\
3 & A. crispus & 32 & $\begin{array}{l}\text { Arends, 1985 } \\
\text { Gaikwad } \text { et al., } 1998\end{array}$ \\
4 & A. natans & 80 & $\begin{array}{l}\text { Arends, 1985 } \\
\text { Yadav \& Gaikwad, 2003 } \\
5\end{array}$ \\
A. satarensis & 26 & Yadav et al., 1989 \\
6 & A. undulatus & 70 & $\begin{array}{l}\text { Arends, 1985; Gaikwad } \text { et al., } 1998 \\
\text { Arends, 1985; Gaikwad } \text { et al., } 1998\end{array}$ \\
\hline
\end{tabular}
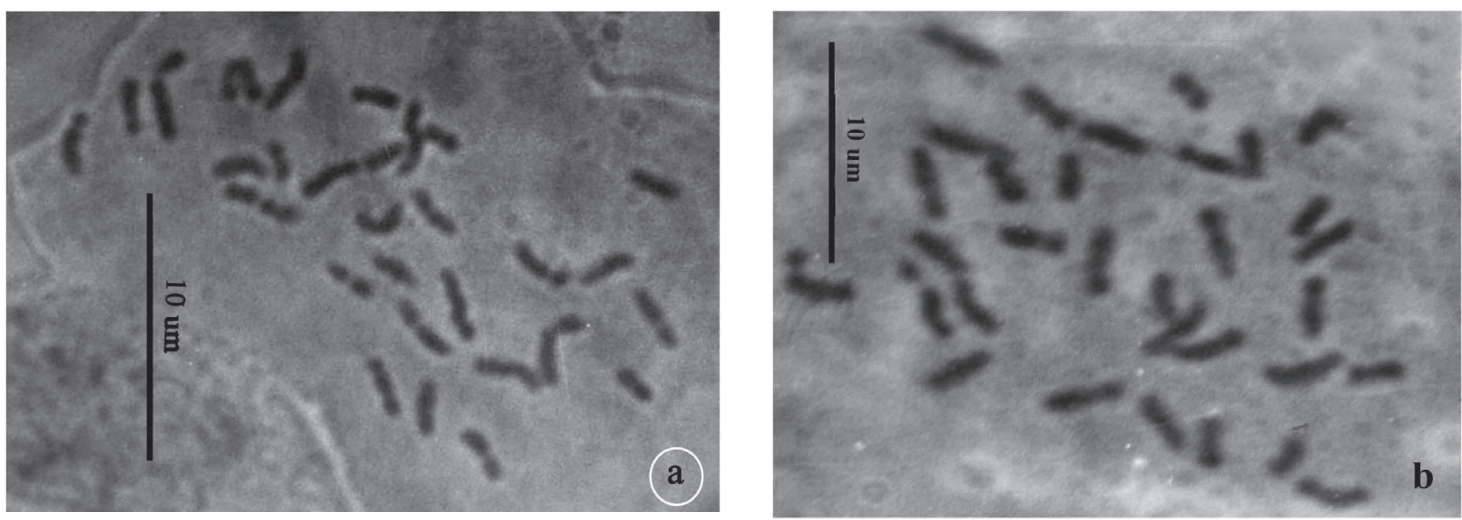

Figure 1: a. Aponogeton appendiculatus $(2 \mathrm{n}=30)$; b. Aponogeton crispus $(2 \mathrm{n}=30)$ 
Table 2. Values of chromosome pairs of A. appendiculatus Bruggen

\begin{tabular}{|c|c|c|c|c|c|}
\hline \multirow{2}{*}{$\begin{array}{l}\text { Number of } \\
\text { chromosome } \\
\text { pairs }\end{array}$} & \multicolumn{3}{|c|}{ Length of chromosomes in $\mu \mathrm{m}$} & \multirow{2}{*}{$\begin{array}{l}\text { Difference between } \\
\text { long arm and } \\
\text { short arm in } \mu \mathrm{m} \\
\mathrm{D}=\mathrm{L}-\mathrm{S}\end{array}$} & \multirow{2}{*}{$\begin{array}{l}\text { Ratio between } \\
\text { long arm and } \\
\text { short arm in } \mu \mathrm{m} \\
\mathrm{R}=\mathrm{L} / \mathrm{S}\end{array}$} \\
\hline & $\begin{array}{l}\text { Short arm } \\
\text { (S) }\end{array}$ & $\begin{array}{l}\text { Long arm } \\
\text { (L) }\end{array}$ & $\begin{array}{l}\text { Total } \\
(\mathrm{S}+\mathrm{L})\end{array}$ & & \\
\hline 1 & $1.69 \pm 0.50$ & $2.84 \pm 0.51$ & $4.53 \pm 0.46$ & 1.15 & 1.68 \\
\hline 2 & $1.08 \pm 0.16$ & $2.72 \pm 0.34$ & $3.80 \pm 0.40$ & 1.64 & 2.51 \\
\hline 3 & $1.67 \pm 0.22$ & $2.14 \pm 0.22$ & $3.81 \pm 0.37$ & 0.47 & 1.28 \\
\hline 4 & $1.38 \pm 0.32$ & $2.09 \pm 0.31$ & $3.47 \pm 0.22$ & 0.71 & 1.51 \\
\hline 5 & $0.97 \pm 0.14$ & $2.39 \pm 0.35$ & $3.36 \pm 0.27$ & 1.42 & 2.46 \\
\hline 6 & $0.96 \pm 0.13$ & $2.08 \pm 0.27$ & $3.04 \pm 0.22$ & 1.12 & 2.08 \\
\hline 7 & $1.29 \pm 0.16$ & $1.76 \pm 0.15$ & $3.05 \pm 0.52$ & 0.47 & 1.36 \\
\hline 8 & $0.96 \pm 0.20$ & $1.91 \pm 0.16$ & $2.87 \pm 0.27$ & 0.95 & 1.98 \\
\hline 9 & $1.02 \pm 0.12$ & $1.74 \pm 0.25$ & $2.76 \pm 0.27$ & 0.72 & 1.70 \\
\hline 10 & $0.91 \pm 0.09$ & $1.71 \pm 0.27$ & $2.62 \pm 0.23$ & 0.8 & 0.87 \\
\hline 11 & $1.04 \pm 0.12$ & $1.55 \pm 0.22$ & $2.59 \pm 0.24$ & 0.51 & 1.49 \\
\hline 12 & $0.91 \pm 0.13$ & $1.45 \pm 0.22$ & $2.36 \pm 0.19$ & 0.54 & 1.59 \\
\hline 13 & $0.89 \pm 0.07$ & $1.29 \pm 0.14$ & $2.18 \pm 20.0$ & 0.54 & 1.44 \\
\hline 14 & $0.86 \pm 0.07$ & $1.25 \pm 0.25$ & $2.11 \pm 0.19$ & 0.39 & 1.45 \\
\hline 15 & $0.87 \pm 0.06$ & $1.04 \pm 0.15$ & $1.91 \pm 0.18$ & 0.17 & 1.19 \\
\hline
\end{tabular}

Table 3. Values of chromosome pairs of A. crispus Thunb.

\begin{tabular}{llllll}
\hline $\begin{array}{l}\text { Number of } \\
\text { chromosome } \\
\text { pairs }\end{array}$ & \multicolumn{3}{c}{ Length of chromosomes in $\mu \mathrm{m}$} & $\begin{array}{l}\text { Difference between } \\
\text { long arm and } \\
\text { short arm in } \mu \mathrm{m} \\
\mathrm{D}=\mathrm{L}-\mathrm{S}\end{array}$ & $\begin{array}{l}\text { Ratio between } \\
\text { long arm and } \\
\text { short arm in } \mu \mathrm{m} \\
\mathrm{R}=\mathrm{L} / \mathrm{S}\end{array}$ \\
& $\begin{array}{l}\text { Short arm } \\
\text { (S) }\end{array}$ & $\begin{array}{l}\text { Long arm } \\
\text { (L) }\end{array}$ & $\begin{array}{l}\text { Total } \\
(\mathrm{S}+\mathrm{L})\end{array}$ & & \\
\hline 1 & $1.32 \pm 0.39$ & $2.84 \pm 0.25$ & $4.16 \pm 0.49$ & 1.52 & 2.15 \\
2 & $1.05 \pm 0.19$ & $2.59 \pm 0.24$ & $3.64 \pm 0.23$ & 1.54 & 2.46 \\
3 & $1.38 \pm 0.40$ & $2.07 \pm 0.17$ & $3.45 \pm 0.39$ & 0.69 & 1.5 \\
4 & $0.92 \pm 0.08$ & $2.33 \pm 0.30$ & $3.25 \pm 0.31$ & 1.41 & 2.53 \\
5 & $1.03 \pm 0.18$ & $2.01 \pm 0.26$ & $3.04 \pm 0.26$ & 0.98 & 1.95 \\
6 & $0.87 \pm 0.09$ & $2.0 \pm 0.26$ & $2.87 \pm 0.25$ & 1.13 & 2.29 \\
7 & $1.15 \pm 0.28$ & $1.71 \pm 0.15$ & $2.86 \pm 0.33$ & 0.56 & 1.48 \\
8 & $1.01 \pm 0.11$ & $1.71 \pm 0.23$ & $2.72 \pm 0.26$ & 0.7 & 1.69 \\
9 & $0.94 \pm 0.09$ & $1.67 \pm 0.19$ & $2.61 \pm 0.22$ & 0.73 & 1.77 \\
10 & $0.94 \pm 0.14$ & $1.60 \pm 0.22$ & $2.54 \pm 0.26$ & 0.41 & 1.70 \\
11 & $1.00 \pm 0.08$ & $1.41 \pm 0.29$ & $2.41 \pm 0.26$ & 0.41 & 1.41 \\
12 & $0.93 \pm 0.14$ & $1.33 \pm 0.16$ & $2.26 \pm 0.25$ & 0.4 & 1.43 \\
13 & $0.92 \pm 0.06$ & $1.16 \pm 0.16$ & $2.08 \pm 0.36$ & 0.24 & 1.26 \\
14 & $0.80 \pm 0.10$ & $1.15 \pm 0.14$ & $1.95 \pm 25.0$ & 0.35 & 1.43 \\
15 & $0.87 \pm 0.8$ & $1.08 \pm 0.11$ & $1.95 \pm 0.27$ & 0.21 & 1.24 \\
16 & $0.64 \pm 0.17$ & $0.97 \pm 39.0$ & $1.64 \pm 41.0$ & 0.33 & 1.51 \\
\hline & & & & &
\end{tabular}




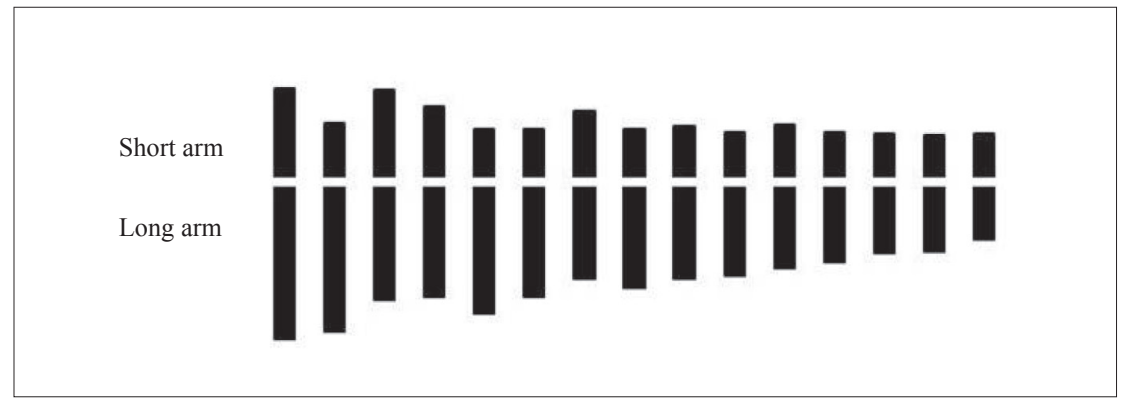

Figure 2: Ideogram for haploid complement of Aponogeton appendiculatus Bruggen

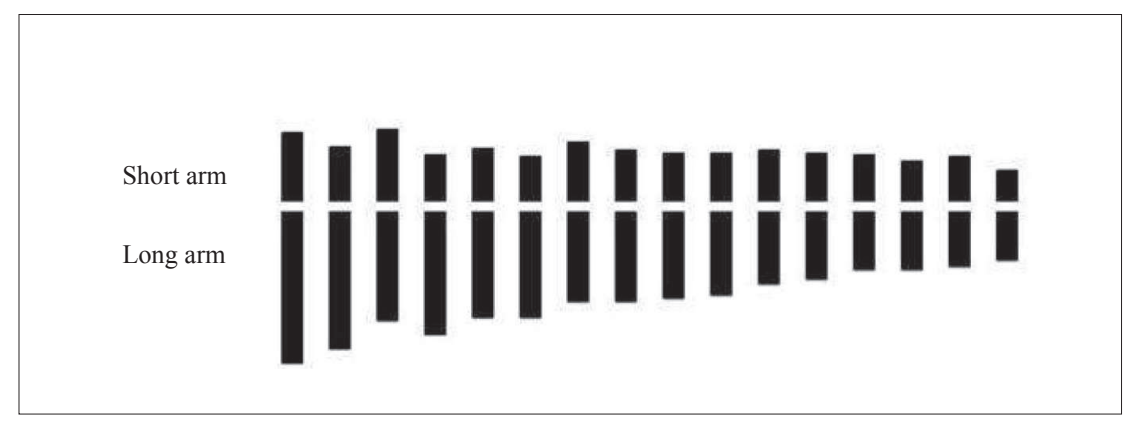

Figure 3. Ideogram for haploid complement of Aponogeton crispus Thunb.

Karyotype formula:

Aponogeton appendiculatus H. Bruggen. Blumea 16: 265 , f. $5.1968=18 \mathrm{~m}+12 \mathrm{sm}$.

Aponogeton crispus Thunb., Nov. Gen. 4: 73. 1781 ('crispum').

A somatic chromosome number of $2 \mathrm{n}=32$ was observed in the species (Figure 1b). In general, the chromosomes were short. The chromosome length ranged between $1.64-4.16 \mu \mathrm{m}$ with a mean length of $2.71 \mu \mathrm{m}$ and an absolute length of $43.43 \mu \mathrm{m}$ (Table 3 ). TF \% was 36.31 $\mu \mathrm{m}$ and the symmetrical index was 57.05 . The ideogram of the species is represented in Figure 3.

Karyotype formula:

Aponogeton crispus Thunb., Nov. Gen. 4: 73. 1781. $=16 \mathrm{~m}+16_{\mathrm{sm}}$

\section{DISCUSSION}

This paper reports a somatic chromosome number of $2 \mathrm{n}=30$ for $A$. appendiculatus and $2 \mathrm{n}=32$ for $A$. crispus. Earlier records of the somatic chromosome numbers for Indian Aponogeton species (Table 1) showed that the species, namely $A$. appendiculatus, $A$. crispus and
A. satarensis have a low ploidy level and that they reproduce sexually; however, the species, namely A. bruggenii, $A$. natans and $A$. undulatus show high ploidy levels. The latter species are sexually sterile and reproduced by vegetative propagation.

Karyotypic analysis of $A$. appendiculatus and A. crispus showed a low ratio of the lengths of the longest and shortest chromosomes. The chromosomes showed a closely graded size with median region and submedian primary constrictions. The karyotype of both species was reasonably symmetrical, which is supported by the high TF \% (36.31 in A. crispus and 37.11 in A. appendiculatus). A similar type of karyotype was reported for A. satarensis (Yadav et al., 1989). Karyotype analysis of three sexually reproducing species suggests the primitiveness of $A$. satarensis among them, which is a paleoendemic species surviving on a few plateaus of higher altitude $(900-1100 \mathrm{~m})$ in the Northern Western Ghats of India (Ahmedullah \& Nayar, 1986). It is closely related to the Madagascar species $A$. decaryi Jumelle $(2 \mathrm{n}=46)$ and bear living witness for the theory of continental drift (Yadav, 1995b).

Reasonable symmetrical karyotype and chromosomes with median point, median region and submedian primary constriction indicate the general primitiveness of the family Aponogetonaceae (Bruggen, 1985). 


\section{Acknowledgement}

The authors thank the Principal, Walchand College of Arts and Science, Solapur (MS), India and the Department of Science and Technology, Government of India for financial assistance under SERC fast track scheme for young scientists.

\section{REFERENCES}

1. Ahmedullah M. \& Nayar M.P. (1986). Endemic Plants of the Indian Region, p.203. Botanical Survey of India, Calcutta, India.

2. Arends I.J.C. (1985). Somatic chromosome numbers. Monograph of the genus Aponogeton (Aponogetonaceae) (ed. H.W.E. Van Bruggen), pp. $9-10$. Bibliotheca Botanica Heft 137. Stuttgart: E. Schweizerbart'sche Verlagsbuchhandlung (Nägele u. Obermiller).

3. Bruggen H.W.E. Van (1985). Monograph of the genus Aponogeton (Aponogetonaceae), pp. 97. Bibliotheca Botanica Heft 137. Stuttgart: E. Schweizerbart'sche Verlagsbuchhandlung (Nägele u. Obermiller).

4. Burrell P.C. (1939). Root-tip smear method for difficult material. Stain Technology 14: 147 - 149.

5. Davidse G. (1981). Chromosome numbers of miscellaneous Angiosperms. Annals of the Missouri Botanical Garden 68 : $222-224$.

DOI: http://dx.doi.org/10.2307/2398824

6. Gaikwad S.P., Sardesai M.M. \& Yadav S.R. (1998). Naturliche hybriden (?) zwischen Aponogeton appendiculatus H.W.E. Van Bruggen und A. undulatus Roxburgh und ihr Nutzen fur die Aquaristik. Aqua Planta 2: $54-67$.

7. Ghosh D.K. \& Bhattacharya G.N. (1980). Chromosomes in some species of Potamogeton and Aponogeton. Proceedings of the $67^{\text {th }}$ Indian Scientific Congress 3: 53 - 54.

8. Harada I. (1956). Cytological studies in Helobiae, I. chromosome ideograms and a list of chromosomes numbers in seven families. Cytologia 21: $306-328$. DOI: http://dx.doi.org/10.1508/cytologia.21.306

9. Huziwara Y. (1962). Karyotype analysis in some genera of compositae VIII-further studies on the chromosomes of Aster. American Journal of Botany 49: 116 - 119. DOI: http://dx.doi.org/10.2307/2439026
10. Levan A., Fredge L. \& Sandberg A.A. (1964). Nomenclature for centromeric position on chromosomes. Hereditas 52: $201-220$. DOI: http://dx.doi.org/10.1111/j.1601-5223.1964.tb01953.x

11. Misra M.P. (1972). Cytological studies in some Indian Potamogeton and Aponogeton species. Bulletin of the Botanical Society of Bengal 26: 47 - 51.

12. Mishra D. \& Singh N.P. (2001). Endemic and Threatened Flowering Plants of Maharashtra, pp. 254 - 256. Botanical Survey of India, Calcutta, India.

13. Nayar M.P. (1996). Hot Spots of Endemic Plants of India, Nepal and Bhutan, pp. 217. Tropical Botanic Garden and Research Institute, Palode, Thiruvananthapuram, India.

14. Nayar M.P. \& Sastry A.R.K. (eds.). (1987). Red Data Book of Indian Plants, volume 1, pp. 41. Botanical Survey of India, Calcutta, India.

15. Nayar M.P. \& Sastry A.R.K. (eds.). (1988). Red Data Book of Indian Plants, volume 1, pp. 31. Botanical Survey of India, Calcutta, India.

16. Pritchard A.J. (1967). The somatic chromosome of Trifolium cheileri, T. hirtum, T. ligusticum and T. scabrum. Cytologia 20: $323-331$.

17. Raghavan S.R. (1996). Aponogetonaceae. Fascicles of Flora of India, no. 22 (eds. P.K. Hajara \& M. Sanjappa), pp. 123 - 136. Botanical Survey of India, Calcutta, India.

18. Raven P.H. (1975). The bases of Angiosperm phylogeny: cytology. Annals of the Missouri Botanical Gardens 62: $724-764$.

DOI: http://dx.doi.org/10.2307/2395272

19. Sharma A.K. \& Chatterjee T. (1967). Cytotaxonomy of Helobiae with reference to the mode of evolution. Cytologia 32: $286-307$.

DOI: http://dx.doi.org/10.1508/cytologia.32.286

20. Yadav S.R. (1995a). Aponogeton bruggenii Yadav \& Govekar. Aqua Planta 20(1): 3 - 11.

21. Yadav S.R. (1995b). Die hybrid zwishen Aponogeton decaryi Jumelle and Aponogeton satarensis Raghavan et al.. Aqua Planta 20(2): $71-80$.

22. Yadav S.R., Dixit G.B. \& Salunkhe C.B. (1989). Cytological studies in Aponogeton satarensis Raghavan et al.. Current Science 58: $81-82$.

23. Yadav S.R. \& Gaikwad S.P. (2003). Revision of Indian Aponogetonaceae. Bulletine of the Botanical Survey of India 45 (1-4): $39-76$. 